\title{
German physicians warn of genetics risks
}

Munich. The German section of International Physicians for the Prevention of Nuclear War (IPPNW) has called for a full debate in the German parliament on the Council of Europe's proposed Bioethics Convention, claiming that it is not sufficiently restrictive on experiments involving embryos and on genetic screening, and fails to provide adequate protection for the mentally handicapped.

The demand for such debate was made at a meeting in Nuremberg last week held to commemorate the 50th anniversary of the trials of doctors who experimented on concentration camp prisoners during the Nazi era. At the meeting, the IPPNW, whose parent body won the Nobel peace prize in 1985, also called for a moratorium on the development and use of new genetic screening tests until laws have been introduced Past crimes: the conduct of Nazi doctors such as Kar protecting individuals against their possible misuse.

The meeting endorsed the text of a declaration warning that if the draft bioethics convention is approved, there is a serious risk that Germany's dark history of human experimentation will repeat itself. The declaration has already been signed by more than 14,000 individuals, including representatives from the medical, academic and political communities, as well as groups such as charities for the mentally handicapped.

The document was drawn up by Michael Wunder, a psychologist based in Hamburg who works with mentally handicapped people. He argues that the draft convention compromises the first article of the so-called Nuremberg code of 1947, which was written at the end of the doctors' trials to provide a legal basis for ethical scientific research.

The code says that the voluntary consent of the human subject in medical experiments is "essential", and also specifies that anyone taking part in such an experiment must be capable of giving consent. It was modified slightly by the 1964 Helsinki declaration by the World Organization of Physicians to permit experiments without consent on an individual if they are of potential direct benefit to the individual's health.

In contrast, the proposed bioethics convention would allow research to be carried out to determine general mechanisms of a disease suffered by a person incapable of giving consent ('legally incapacitated persons'). This would be of no direct benefit to the patient, but would benefit others afflicted with the same disease in the future. Wunder says that the convention opens a door to potential abuse which may not be easily closed.

The declaration also argues that the convention is too liberal towards embryo experimentation and genetic screening. In fact, the latest draft of the convention takes no stand on the issue of embryo research, requiring only that the embryo 'be protected' under national law in those countries where it is undertaken. Genetic testing would be permitted for health purposes or for scientific

\section{IMAGE UNAVAILABLE FOR COPYRIGHT REASONS}

within the declaration that the convention would eventually allow germ-cell therapy, for example, are unfounded, as this is expressly ruled out in the convention.

"There were a lot of lies and misinterpredo tation of the convention which was not a lack of knowledge, but a political intention [to hinder genetics research]," he says. "I feel our history is being manipulated for this purpose".

Honnefelder argues that the convention, which has been considerably revised during the past two years, is extremely restrictive, particularly the clause allowing research on legally incapacitated persons. It specifies that there must be no alternative means for doing the research, whose aim must be restricted to a better understanding of the disease from which the patient suffers. The research must not harm the patient in any way, and must be research linked to health purposes, accompanied by appropriate genetic counselling.

Wunder's document was initially drawn up for a meeting of the IPPNW's working group on the history of euthanasia held last June in Grafenecker, a small town in southwest Germany, where 10,000 mentally handicapped and psychologically ill people were gassed by the Nazis in 1940. Now known as the 'Grafenecker declaration' on bioethics, the declaration was endorsed at the Nuremberg meeting.

But Ludger Honnefelder, director of the Bonn Institute for Science and Ethics, and a member of the Council of Europe's expert committee responsible for the drawing up of the convention, rejects the declaration's criticisms, which he says are based on a "wilful" misunderstanding of the text of the convention. He points out that claims made

\section{Russian academy opts again for Osipov}

Moscow. Yuri Osipov has been re-elected president of the Russian Academy of Sciences (RAS) after a tense campaign in which he promised to support all branches of Russian science, despite the serious problems of under-funding.

Osipov had given a pessimistic report to the RAS presidium, saying that "the historical reserves of the academy's intellectual and material stability are fully exhausted". He pledged to make all branches of science "equal in poverty".

In contrast, his nearest rival in the election, Evgeny Velikhov, had promised to back "elite" science. He particularly wanted to support nuclear physics, and described subjects such as palaeontology as "trifles". Velikhov insisted that only viable areas of science should be saved from collapse. He promised to find new ways of financing research, but he failed to mention details.
The third candidate was Valentin Koptyug, an RAS vice-president and presidium. Koptyug is also a member of the central committee of the Russian Communist Party. He faced a heavy defeat and withdrew from the contest.

In the first stage of the election, the RAS presidium supported Osipov by 23 votes to 15 and recommended him to the general assembly as its candidate for president. Of more than 1,000 academicians who took part in the general assembly ballot last week, 777 voted for Osipov.

The general assembly opened with a speech from Viktor Chernomyrdin, the Russian prime minister, in which he said that "it was our tragic mistake at the beginning of Perestroika to consider science to be the same branch of the national economy as, say, industry". chairman of the academy's Siberian branch 